\title{
Karakteristik Beras Analog Berindeks Glisemik Rendah dari Oyek dengan Penambahan Berbagai Jenis Kacang-Kacangan
}

\author{
Characteristics of Low Glycemic Index Artificial Rice from Oyek with Addition of Various Legumes \\ Bayu Kanetro", Dwiyati Pujimulyani', Sri Luwihana', Alimatus Sahrah² \\ ${ }^{1}$ Program Studi Teknologi Hasil Pertanian, Universitas Mercu Buana Yogyakarta \\ ${ }^{2}$ Fakultas Psikologi, Universitas Mercu Buana Yogyakarta, Jl. Wates Km. 10 Yogyakarta 55753 \\ Email: bayu_kanetro@yahoo.co.id
}

Submisi: 2 November 2015; Penerimaan: 14 September 2016

\begin{abstract}
ABSTRAK
Penelitian ini bertujuan menentukan jenis kacang-kacangan yang tepat untuk meningkatkan kadar protein beras analog dari growol kering atau oyek berdasarkan sifat fisik, kimia, sensoris, dan indeks glisemik. Penelitian dilaksanakan dengan rancangan acak lengkap faktor tunggal yaitu jenis kacang-kacangan yang meliputi kacang kedelai, tunggak, koro, dan kacang hijau. Beras analog/artificial dibuat melalui tahap pembuatan adonan yang terdiri campuran tepung kacang-kacangan dan tepung oyek dengan perbandingan 3:7. Selanjutnya dibentuk menyerupai beras, dikukus, dan dikeringkan sehingga diperoleh beras analog yang dapat disimpan. Produk kering dan produk yang siap dikonsumsi (nasi analog) selanjutnya dianalisis tekstur, warna,tingkat kesukaan, dan komposisi proksimat pada beras analog, serta indeks glisemik pada nasi analog. Hasil penelitian menunjukkan bahwa jenis kacang-kacangan berpengaruh terhadap sifat fisik dan tingkat kesukaan beras maupun nasi analog. Jenis kacang-kacangan terbaik adalah kacang hijau yang memberikan tingkat kesukaan nasi analog paling baik dibandingkan jenis kacang-kacangan lainnya dan nilainya sama atau tidak berbeda nyata dengan nasi biasa. Komposisi proksimat beras analog terbaik khususnya kadar proteinnya hampir sama dengan beras biasa, dan IG-nya dikategorikan dalam bahan pangan ber-IG rendah.
\end{abstract}

Kata kunci: Beras analog/artificial; ubi kayu; oyek; indeks glisemik; kacang-kacangan

\begin{abstract}
The aim of this research was to determine the best legumes for increasing protein of artificial rice that was made of dried growol or oyek based on physical, sensory charactersitics and glycemic index. The experiment design of this research was randomized complete design with the single factor of legumes type, that were soybean mungbean, vevet bean, and cowpeas. The first step of artificial rice processing was mixing dried oyek and legumes flour with 3:7 ratio. The next step was forming the dough into the same as rice, steaming, and drying for producing artificial rice that could be stored. The products of artificial rice were analyzed for texture, colour, and preference level of dried and steamed procuct, proximate composition of dried product, and glycemic index (IG) of steamed product. The result of this research showed that the type of legumes affected the physical and sensory characteristic of artificial rice. The best legumes for producing artificial rice was mungbean. The preference level of the best product was better than the other legumes, and the same as original rice. The proximate composition especially protein content of the best product was the same as original rice, and its IG was be categorized in low IG food product.
\end{abstract}

Keywords: Artificial rice; cassava; glycemic index; legumes; oyek 


\section{PENDAHULUAN}

Beras adalah makanan pokok utama di Indonesia. Namun saat ini produksi beras dalam negeri tidak mencukupi kebutuhannya, karena peningkatan populasi, bencana alam, dan menurunnya produktivitas lahan pertanian (Saputro dan Rahman, 2011). Untuk mengatasi hal tersebut, saat ini telah dikembangkan beras tiruan atau artificial rice atau beras analog yang dibuat dari bahan bukan padi, biasanya dari campuran berbagai macam tepung misalnya tepung umbi-umbian dan kacang-kacangan. Beberapa peneliti telah mengembangkan beras artificial atau beras analog diantaranya oleh Slamet Budijanto dari Institut Pertanian Bogor yang membuat beras artificial dari campuran jagung, sorgum, dan sagu (Sufa, 2012). Saputro dan Rahman (2011) juga telah membuat beras artficial dengan bahan utama tepung ubi kayu yang dibuat melalui tahap pencampuran tepung ubi kayu dengan tepung porang dan air sampai diperoleh adonan yang tidak lengket. Tahap selanjutnya adalah pencetakan dengan pencetak cookies, pengukusan, pemotongan kecil-kecil dengan bentuk seperti beras, dan diakhiri dengan pengeringan menggunakan cabinet dryer. Penelitian tentang pembuatan beras artificial dari pengembangan oyek ubi kayu belum pernah dilakukan.

Pengembangan beras analog dari oyek pada penelitian ini sejalan dengan peraturan Presiden RI No 22 Tahun 2009 yang menetapkan kebijakan percepatan penganekaragaman konsumsi pangan berbasis sumberdaya lokal. Tujuan kebijakan tersebut antara lain untuk mendukung peningkatan konsumsi umbi-umbian dan kacang-kacangan dengan mengutamakan produksi lokal, sehingga konsumsi beras diharapkan turun sekitar 1,5\% per tahun (Anonim, 2010). Oyek yang merupakan hasil pengeringan growol dapat disimpan dan dimanfaatkan dengan cara dikukus kembali untuk dikonsumsi terutama pada masa "paceklik" atau kekurangan pangan yang biasanya terjadi saat musim kemarau. Oyek maupun growol banyak dikonsumsi di Kulonprogo Yogyakarta yang dibuat melalui tahap fermentasi secara spontan dengan cara perendaman potongan ubi kayu yang telah dikupas dalam air, selanjutnya dipres atau diperas untuk menghilangkan sebagain air. Tahap selanjutnya ampas/padatan dicetak, dikukus untuk menghasilkan growol dan dikeringkan untuk menghasilkan oyek (Luwihana, 2011). Produk sejenis growol yang dikenal di negara lain adalah gari atau rale yang merupakan produk fermentasi ubi kayu menggunakan bakteri asam laktat/ BAL(Eduardo dkk., 2013).

Hambatan pengembangan oyek sebagai pangan pokok adalah kadar proteinnya lebih rendah daripada nasi. Kadar protein ubi kayu sebagai bahan dasar oyek sangat rendah, yaitu sekitar 1\% (Stupak dkk., 2006). Stephenson dkk. (2010) menyampaikan bahwa menurut WHO kecukupan protein dibandingkan energi atau protein: energy ratio (P:E) adalah $>5 \%$. Oleh karena itu konsumsi ubi kayu dalam jangka lama mengakibatkan kekurangan protein, seperti yang terjadi pada anak-anak Nigeria dan Kenya yang mengkonsumsi ubi kayu berturut-turut sebesar 35 dan $89 \%$ dalam dietnya (Stephenson dkk., 2010). Pada penelitian ini kacang-kacangan, yaitu kacang kedelai, kacang hijau, kara, dan tunggak digunakan untuk meningkatkan kadar protein oyek. Penelitian sebelumnya menunjukkan bahwa penambahan tepung kacang tunggak 30\% mampu meningkatkan kadar protein menjadi hampir sama dengan beras. Namun oyek dengan penambahan kacang tunggak dalam bentuk tepung maupun isolat protein tersebut belum disukai karena warna menjadi lebih gelap atau keabu-abuan dan ada beany flavor atau langu (Luwihana dan Kanetro, 2013). Oleh karena itu perlu diketahui jenis kacangkacangan yang tepat untuk meningkatkan kadar protein oyek untuk dikembangkan menjadi beras analog.

Permasalahan lain pengembangan oyek menjadi beras analog adalah bentuk, warna, dan aroma oyek tidak menyerupai beras. Padahal penelitian sebelumnya menunjukkan bahwa oyek dari campuran ubi kayu dan kacang tunggak memiliki keunggulan dibandingkan beras, yaitu kadar protein dan serat pangan (prebiotik) lebih tinggi serta mengandung bakteri asam laktat/BAL (probiotik) (Kanetro dan Luwihana, 2015). Penelitian sebelumnya juga menunjukkan bahwa oyek dengan penambahan kecambah kacang tunggak mampu menurunkan gula darah dan kolesterol melalui pengujian biologis secara in vivo pada tikus diabetes (Kanetro dkk., 2015a), sehingga oyek berpotensi sebagai pangan fungsional khususnya untuk mencegah diabetes. Hal tersebut kemungkinan salah satunya disebabkan kacang-kacangan merupakan sumber protein dengan banyak kandungan asam amino arginin (Kanetro dan Dewi, 2013). Arginin termasuk asam amino penstimulasi sekresi insulin (Newsholme dkk., 2006).

Pengujian indeks glisemik pada beras analog hasil pengembangan oyek dengan penambahan berbagai kacangkacangan diharapkan dapat mempertegas potensi oyek sebagai pangan fungsional. Penelitian ini bertujuan untuk mengetahui jenis kacang-kacangan yang tepat digunakan sebagai campuran tepung growol/oyek dalam pembuatan beras analog berdasarkan karakteristik fisik, sensoris, dan kimia serta indeks glisemik. Jenis kacang-kacangan yang digunakan adalah kacang kedelai lokal, kacang hijau, kacang kara dan kacang tunggak dengan pertimbangan jenis kacangkacangan tersebut banyak dikonsumsi dan mudah diperoleh, khususnya kacang kara yang banyak dibudidayakan di Kulonprogo di daerah penghasil oyek. 


\section{METODE PENELITIAN}

\section{Bahan}

Bahan yang digunakan dalam penelitian ini tepung oyek yang dibuat dari singkong/ubi kayu (Manihot esculenta) segar jenis putih yang diperoleh di Pasar Telo, Karangkajen dan Pasar Gamping, Yogyakarta dengan ciri-ciri kulit bagian dalam berwarna merah dan warna ubi kayu sesudah dikupas putih, termasuk jenis ubi kayu tidak pahit. Kacang-kacangan meliputi kacang hijau, kedelai, tunggak dan kara diperoleh di UD Hasil Indah, Yogyakarta. Tepung tapioka, sagu dan maizena yang diperoleh di Toko Intisari, Yogyakarta. Bahan kimia untuk uji indeks glisemik di Laboratorium Kesehatan DIY, analisis proksimat dan kalori di Laboratorium Kimia Pangan TPHP UGM, dan bahan kimia untuk uji bakteri asam laktat. Selain itu digunakan bahan kimia untuk analisis kadar lemak, protein, kadar pati, serat kasar, gula total, amilosa amilopektin di Laboratorium Kimia-PHP Universitas Mercu Buana Yogyakarta, antara lain bahan kimia pro analisa (Merk) seperti $\mathrm{HCl}$, indikator MR-BCG, $\mathrm{H}_{3} \mathrm{BO}_{3}, \mathrm{H}_{2} \mathrm{SO}_{4}$, Katalisator berupa campuran $\mathrm{Na}_{2} \mathrm{SO}_{4}$ dan $\mathrm{HgO}$, petroleum eter dan Media MRSA (deMann Rogosa Sharpe Agar) untuk analisis bakteri asam laktat.

\section{Alat}

Alat yang digunakan untuk penelitian ini meliputi kompor listrik (Rinnai TL-200C), cabinet dryer (Memmert), gilingan mie atlas, loyang, blender, peralatan ayak, panci, rice cooker, timbangan digital (Denver Instrumen M-310), gelas ukur, color reader CR-10 (Konica Minolta), LFRATexture Analyzer (Brookfield), cawan, nampan dan sendok, mesin pencetak beras Maksindo-Agrowindo, dan seperangkat alat untuk analisis kimia proksimat, kalori dan indeks glisemik.

\section{Tahapan Penelitian}

Penelitian dilaksanakan dengan rancangan acak lengkap (RAL) faktor tunggal (Gomez dan Gomez, 1995).

\section{Proses pembuatan tepung oyek}

Proses pembuatan obyek merujuk pada penelitian Luwihana (2011) yang diawali dengan sortasi bahan baku yaitu melakukan pemilihan ubi kayu yang masih segar, dengan kondisi fisik yang masih utuh dan tidak cacat atau terpotong, selanjutnya dikupas. Pengupasan bertujuan untuk memisahkan daging singkong dengan kulit, baik kulit dalam maupun kulit luar. Ubi kayu yang telah dikupas kemudian dicuci hingga 2-3 kali dengan air mengalir. Ubi kayu yang telah bersih kemudian dipotong-potong dengan ukuran $\pm 5 \mathrm{~cm}$ agar diperoleh ukuran yang seragam dan mempermudah proses perendaman. Ubi kayu yang telah dipotong-potong kemudian direndam menggunakan air dengan perbandingan 1:3 (b/v) yaitu ubi kayu sebanyak $1 \mathrm{~kg}$ direndam menggunakan air sebanyak 3 liter selama 5 hari. Selanjutnya dilakukan pemanenan yang meliputi proses pencucian, penyaringan, dan pemerasan. Tahap pencucian dilakukan menggunakan air mengalir yang bertujuan untuk menghilangkan bau dan mengurangi tingkat keasaman bahan. Proses penyaringan dilakukan menggunakan kain saring yang kemudian dilanjutkan dengan proses pemerasan. Proses pemerasan bertujuan untuk megurangi air yang ada di dalam bahan dan diperoleh pati singkong.

Proses selanjutnya adalah pengepresan menggunakan hydrolic press untuk mengurangi kadar air. Ampas hasil pengepresan ini disebut growol. Proses selanjutnya yaitu pengeringan menggunakan cabinet dryer pada suhu 50-60 ${ }^{\circ} \mathrm{C}$ selama 2,5-3 jam dan digiling sampai diperoleh tepung growol kering yang disebut tepung oyek. Kondisi suhu dan waktu pengeringan tersebut diperoleh berdasarkan orientasi yang dilakukan pada penelitian sebelumnya (Luwihana dan Kanetro, 2013), yaitu untuk mengeringkan growol dari ubi kayu sebanyak $1 \mathrm{~kg}$ menjadi oyek pada pengaturan suhu maksimal mesin pengering $\left(50-60{ }^{\circ} \mathrm{C}\right)$ sampai kadar air mendekati beras padi (10-12\%) membutuhkan waktu 2,5-3 jam.

\section{Proses pembuatan tepung kacang-kacangan}

Kacang-kacangan yang digunakan dalam pembuatan beras analog antara lain kacang hijau, kacang koro, kacang tunggak dan kacang kedelai. Cara pembuatan tepung kacangkacangan tersebut meliputi tahap sortasi, pengilingan dan pengayakan 60 mesh (Kanetro dkk., 2015b). Sortasi bertujuan untuk memisahkan kacang yang tidak utuh dan kotoran yang terikut. Tahap selanjutnya yaitu penggilingan yang bertujuan untuk mengubah ukuran kacang menjadi halus. Tahap terakhir yaitu pengayakan 60 mesh yang bertujuan untuk mendapatkan ukuran tepung kacang yang halus dan seragam.

\section{Proses pembuatan beras analog dari oyek ubi kayu}

Pembuatan beras analog dari tepung growol mentah menggunakan rasio tepung oyek: tepung kacang 70:30 berdasarkan penelitian Kanetro dkk. (2015). Adonan sebanyak $1000 \mathrm{~g}$ terdiri dari tepung obyek sebanyak 700 g dan tepung kacang 300 g. Bahan lain yang ditambahkan dalam adonan adalah pati maizena sebanyak 3\% dari jumlah adonan. Dari 1000 g adonan menggunakan penambahan tepung maizena $30 \mathrm{~g}$. Tujuan penambahan tepung maizena adalah untuk membentuk tekstur beras menjadi lebih kokoh dan tidak mudah rapuh. Hal ini berdasarkan orientasi yang menunjukkan bahwa pada percobaan tanpa penambahan pati maka adonan tidak bisa dicetak menjadi berbentuk beras. 
Adonan tersebut dicampur dalam satu wadah kemudian ditambah dengan air masak sebanyak $400 \mathrm{~mL}$. Adonan dicampur sampai homogen, kemudian dimasukkan ke dalam mesin pencetak beras. Beras yang sudah tercetak selanjutnya dikukus selama 15 menit. Pengukusan bertujuan untuk membuat beras menjadi setengah matang. Tahap selanjutnya yaitu pengeringan menggunakan cabinet dryer pada suhu 50-60 ${ }^{\circ} \mathrm{C}$ selama 2,5-3 jam sampai beras menjadi kering. Beras analog yang telah kering selanjutnya ditimbang dan dimasukkan ke dalam kemasan plastik dan siap dianalisis.

\section{Analisis}

Analisis yang dilakukan pada penelitian ini meliputi: analisis sifat fisik yaitu tekstur menggunakan LFRA Texture Analyzer dan warna menggunakan Color reader CR-10. Analisis sifat sensoris (Kartika dkk., 1992) tingkat kesukaan terhadap warna, bau, rasa, tekstur, dan kesukaan keseluruhan pada produk beras - nasi artificial/analog dan kontrol beras-nasi padi IR64. Pengujan sensoris tingkat kesukaan dilaksanakan oleh 20 panelis yang memberikan penilaian terhadap produk dengan skala penilaian 1 sampai 7 yaitu nilai $1=$ sangat suka, nilai $2=$ suka, nilai $3=$ agak suka, nilai $4=$ antara suka dan tidak suka (netral), nilai $5=$ agak tidak suka, nilai $6=$ tidak suka dan nilai $7=$ sangat tidak suka.

Analisis indeks glisemik menurut metode Standar Badan Pengawasan Obat dan Makanan (Anonim, 2011). Analisis kimia proksimat meliputi kadar air metode pemanasan dalam oven, abu metode furnace, kadar lemak metode soxhlet, kadar protein metode mikrokjeldahl dan kadar karbohidrat by difference serta kalori menurut AOAC (1995). Selainitu juga dianalisis kadar pati, serat kasar dan gula total metode Nelson Somogy menurut AOAC (1995).

Data yang diperoleh (selain analisis kimia) dianalisis statistik menggunakan analisis varian (ANOVA) dan apabila ada pengaruh dilanjutkan uji beda nyata Duncan Multiple Range Test (DMRT) (Gomez, dan Gomez, 1995) yang dikerjakan dengan program komputer SPSS for windows evaluation version pada tingkat kepercayaan $95 \%$.

\section{HASIL DAN PEMBAHASAN}

\section{Sifat Fisik Beras dan Nasi Analog}

Hasil analisis sifat fisik tekstur disajikan pada Tabel 1 dan 2, sedangkan warna disajikan pada Tabel 3 dan 4 . Pada tabel tersebut terlihat bahwa jenis kacang-kacangan berpengaruh terhadap sifat fisik tekstur maupun warna. Hal ini disebabkan adanya perbedaan komposisi kimia dan warna berbagai jenis kacang-kacangan. Kadar karbohidrat kacang hijau paling tinggi dibandingkan jenis kacang kacangan lainnya (Kanetro dan Hastuti, 2006), sehingga kemungkinan hal ini mengakibatkan tekstur beras dengan penambahan kacang hijau paling tinggi.

Pada Tabel 1 terlihat bahwa jenis kacang-kacangan terbaik adalah kacang hijau karena tekstur kekerasannya paling mendekati kontrol (beras biasa/padi). Nilai kekerasan beras analog ternyata jauh lebih rendah dibandingkan dengan beras kontrol. Tabel 2 menunjukkan bahwa tekstur kekerasan nasi analog dengan penambahan kacang hijau hampir sama dengan nasi biasa/kontrol, sedangkan deformasinya tidak berbeda nyata pada semua jenis kacang-kacangan. Nilai deformasi yang menunjukkan elastisitas atau kekenyalan nasi analog hampir sama dengan nasi kontrol.

Hasil analisis warna beras analogdengan penambahan berbagai kacang-kacangan menunjukkan perbedaan nyata antar jenis kacang-kacangan, meskipun nilainya hampir sama dengan beras kontrol. Sedangkan warna nasi analog yang paling mendekati nasi kontrol adalah nasi analog dengan penambahan kacang hijau. Oleh karena itu berdasarkan pengujian sifat fisik secara umum dapat disimpulkan bahwa jenis kacang-kacangan yang tepat digunakan untuk meningkatkan kadar protein beras analog hasil pengembangan oyek adalah kacang hijau.

Tabel 1. Tekstur kekerasan beras analog dengan penambahan berbagai jenis kacang-kacangan

\begin{tabular}{lc}
\hline \multicolumn{1}{c}{ Jenis kacang-kacangan } & Tekstur kekerasan $(\mathrm{g})$ \\
\hline Kacang hijau & $1061,50^{\mathrm{c}}$ \\
Kacang kedelai & $717,50^{\mathrm{b}}$ \\
Kacang tunggak & $572,00^{\mathrm{a}}$ \\
Kacang kara & $579,75^{\mathrm{a}}$ \\
Kontrol Beras IR 64 & $3549,75^{\mathrm{d}}$ \\
\hline
\end{tabular}

Keterangan: angka yang diikuti dengan notasi huruf yang sama pada kolom yang sama menunjukkan tidak ada beda nyata $(p<0,05)$

Tabel 2. Tekstur kekerasan dan deformasi nasi analog dengan penambahan berbagai jenis kacang-kacangan

\begin{tabular}{lcc}
\hline Jenis kacang-kacangan & Kekerasan $(\mathrm{g})$ & Deformasi (\%) \\
\hline Kacang hijau & $147,00^{\mathrm{b}}$ & $59,78^{\mathrm{a}}$ \\
Kacang kedelai & $86,50^{\mathrm{ab}}$ & $56,35^{\mathrm{a}}$ \\
Kacang tunggak & $118,25^{\mathrm{ab}}$ & $63,35^{\mathrm{a}}$ \\
Kacang kara & $60,25^{\mathrm{a}}$ & $57,51^{\mathrm{a}}$ \\
Kontrol Nasi IR 64 & $135,75^{\mathrm{b}}$ & $46,535^{\mathrm{a}}$ \\
\hline
\end{tabular}

Keterangan: angka yang diikuti dengan notasi huruf yang sama pada kolom yang sama menunjukkan tidak ada beda nyata $(p<0,05)$ 
Tabel 3. Warna beras analog dengan penambahan berbagai jenis kacang-kacangan

\begin{tabular}{lccc}
\hline \multicolumn{1}{c}{ Jenis kacang-kacangan } & $\mathrm{L}$ & $\mathrm{a}$ & $\mathrm{b}$ \\
\hline Kacang hijau & $57,45^{\mathrm{bc}}$ & $6,80^{\mathrm{b}}$ & $15,50^{\mathrm{b}}$ \\
Kacang kedelai & $51,95^{\mathrm{a}}$ & $9,35^{\mathrm{d}}$ & $18,10^{\mathrm{c}}$ \\
Kacang tunggak & $57,80^{\mathrm{c}}$ & $6,10^{\mathrm{a}}$ & $13,10^{\mathrm{a}}$ \\
Kacang kara & $57,10^{\mathrm{b}}$ & $8,25^{\mathrm{c}}$ & $15,70^{\mathrm{b}}$ \\
Kontrol Beras IR 64 & $48,95^{\mathrm{a}}$ & $7,10^{\mathrm{b}}$ & $14,70^{\mathrm{ab}}$ \\
\hline
\end{tabular}

Keterangan: angka yang diikuti dengan notasi huruf yang sama pada kolom yang sama menunjukkan tidak ada beda nyata $(p<0,05)$

Tabel 4. Warna nasi analog dengan penambahan berbagai jenis kacang-kacangan

\begin{tabular}{lccc}
\hline Jenis kacang-kacangan & $\mathrm{L}$ & $\mathrm{a}$ & $\mathrm{b}$ \\
\hline Kacang hijau & $45,40^{\mathrm{d}}$ & $6,00^{\mathrm{ab}}$ & $14,85^{\mathrm{b}}$ \\
Kacang kedelai & $40,85^{\mathrm{c}}$ & $11,50^{\mathrm{d}}$ & $23,90^{\mathrm{d}}$ \\
Kacang tunggak & $36,60^{\mathrm{a}}$ & $9,40^{\mathrm{c}}$ & $17,40^{\mathrm{bc}}$ \\
Kacang kara & $37,00^{\mathrm{b}}$ & $8,40^{\mathrm{b}}$ & $16,40^{\mathrm{b}}$ \\
Kontrol Nasi IR 64 & $47,20^{\mathrm{d}}$ & $3,45^{\mathrm{a}}$ & $8,25^{\mathrm{a}}$ \\
\hline
\end{tabular}

Keterangan: angka yang diikuti dengan notasi huruf yang sama pada kolom yang sama menunjukkan tidak ada beda nyata $(p<0,05)$

\section{Sifat Sensoris Beras dan Nasi Analog}

Hasil pengujian sensoris beras dan nasi analog berturutturut disajikan pada Tabel 5 dan Tabel 6 yang menunjukkan bahwa makin kecil nilai maka produk makin disukai. Berdasarkan Tabel tersebut diketahui bahwa jenis kacangkacangan terbaik adalah kacang hijau, bahkan nilai kesukaan keseluruhan beras dan nasi analog dengan penambahan kacang hijau tidak berbeda nyata dibandingkan beras dan nasi kontrol (beras padi IR 64).

Tabel 5. Tingkat kesukaan beras analog dengan penambahan berbagai jenis kacang-kacangan

\begin{tabular}{lrccc}
\hline Jenis kacang-kacangan & \multicolumn{1}{c}{ Bau } & Warna & Tekstur & Keseluruhan \\
\hline Kacang hijau & $2,10^{\text {ab }}$ & $1,65^{\mathrm{a}}$ & $1,95^{\mathrm{a}}$ & $1,85^{\mathrm{ab}}$ \\
Kacang kedelai & $4,30^{\mathrm{c}}$ & $3,40^{\mathrm{c}}$ & $2,90^{\mathrm{c}}$ & $3,80^{\mathrm{d}}$ \\
Kacang tunggak & $2,45^{\mathrm{b}}$ & $2,65^{\mathrm{b}}$ & $2,70^{\mathrm{bc}}$ & $2,90^{\mathrm{c}}$ \\
Kacang kara & $2,25^{\mathrm{a}} \mathrm{b}$ & $1,90^{\mathrm{a}}$ & $2,1^{\text {sab }}$ & $2,20^{\mathrm{b}}$ \\
Kontrol (Beras IR 64) & $1,80^{\mathrm{a}}$ & $1,55^{\mathrm{a}}$ & $2,05^{\mathrm{a}}$ & $1,70^{\mathrm{a}}$ \\
\hline
\end{tabular}

Keterangan: angka yang diikuti dengan notasi huruf yang sama pada kolom yang sama menunjukkan tidak ada beda nyata $(p<0,05)$
Tabel 6. Tingkat kesukaan nasi analog dengan penambahan berbagai jenis kacang-kacangan

\begin{tabular}{lccccc}
\hline $\begin{array}{l}\text { Jenis kacang- } \\
\text { kacangan }\end{array}$ & Bau & Warna & Tekstur & Rasa & Keseluruhan \\
\hline Kacang hijau & $1,90^{\mathrm{ab}}$ & $1,60^{\mathrm{a}}$ & $1,65^{\mathrm{a}}$ & $1,65^{\mathrm{a}}$ & $1,55^{\mathrm{a}}$ \\
$\begin{array}{l}\text { Kacang } \\
\text { kedelai }\end{array}$ & $3,80^{\mathrm{c}}$ & $3,20^{\mathrm{b}}$ & $3,20^{\mathrm{c}}$ & $3,75^{\mathrm{c}}$ & $3,90^{\mathrm{c}}$ \\
$\begin{array}{l}\text { Kacang } \\
\text { tunggak }\end{array}$ & $4,30^{\mathrm{c}}$ & $2,85^{\mathrm{b}}$ & $2,55^{\mathrm{b}}$ & $2,50^{\mathrm{b}}$ & $2,75^{\mathrm{b}}$ \\
$\begin{array}{l}\text { Kacang kara } \\
\begin{array}{l}\text { Kontrol } \\
\text { (Beras IR 64) }\end{array}\end{array}$ & $2,25^{\mathrm{abc}}$ & $2,70^{\mathrm{b}}$ & $2,65^{\mathrm{bc}}$ & $2,70^{\mathrm{b}}$ & $2,85^{\mathrm{b}}$ \\
\hline
\end{tabular}

Keterangan: angka yang diikuti dengan notasi huruf yang sama pada kolom yang sama menunjukkan tidak ada beda nyata $(p<0,05)$

\section{Sifat Kimia Beras Analog}

Komposisi kimia produk beras analog disajikan pada Tabel 7 yang menunjukkan bahwa penambahan tepung kacang-kacangan dapat meningkatkan kadar protein beras analog hampir sama dengan beras biasa. Potensi beras analog sebagai pangan pokok ditunjukkan dengan kadar karbohidrat yang tinggi dan bisa memberikan kalori yang lebih tinggi daripada beras biasa. Nilai kalori beras analog dengan penambahan kacang-kacangan juga lebih tinggi daripada beras analog yang dibuat tanpa penambahan kacangkacangan. Hal ini kemungkinan disebabkan kadar lemaknya lebih tinggi dan kadar serat lebih rendah.

Tabel 8 menunjukkan bahwa komposisi kimia karbohidrat beras analog dengan penambahan kacangkacangan. Kadar pati produk paling tinggi dibandingkan jenis karbohidrat lain yang mengindikasikan bahwa pati masih merupakan sumber kalori utama, sehingga beras analog ini sesuai sebagai pangan pokok pengganti beras padi yang mengandung kadar pati tinggi sebagai sumber kalori utama (Anonim, 1996). Berdasarkan penelitian sebelumnya diketahui kadar serat oyek sekitar 1,84\%bb (Luwihana dan

Tabel 7. Komposisi kimia beras analogdengan penambahan berbagai kacang-kacangan

\begin{tabular}{lcccccc}
\hline \multicolumn{1}{c}{ Sampel } & $\begin{array}{c}\text { Air } \\
(\% \mathrm{bb})\end{array}$ & $\begin{array}{c}\text { Abu } \\
(\% \mathrm{bb})\end{array}$ & $\begin{array}{c}\text { Lemak } \\
(\% \mathrm{bb})\end{array}$ & $\begin{array}{c}\text { Protein } \\
(\% \mathrm{bb})\end{array}$ & $\begin{array}{c}\text { Karbohidrat } \\
\text { by diff }(\%)\end{array}$ & $\begin{array}{c}\text { Kalori } \\
(\mathrm{Kal} / 100 \mathrm{~g})\end{array}$ \\
\hline $\begin{array}{l}\text { Beras analog }+ \\
\text { kacang kedelai }\end{array}$ & 7,78 & 1,72 & 2,24 & 10,17 & 78,08 & 349,45 \\
$\begin{array}{l}\text { Beras analog+ } \\
\text { kacang hijau }\end{array}$ & 9,77 & 1,23 & 0,54 & 6,53 & 81,92 & 337,13 \\
$\begin{array}{l}\text { Beras analog }+ \\
\text { kacang kara }\end{array}$ & 7,31 & 1,24 & 0,32 & 6,78 & 84,34 & 345,09 \\
$\begin{array}{l}\text { Beras analog } \\
\text { +kacang tunggak }\end{array}$ & 4,74 & 1,17 & 0,59 & 6,35 & 87,15 & 356,82 \\
$\begin{array}{l}\text { Beras IR 64 } \\
\text { (kontrol) }\end{array}$ & 13,88 & 0,47 & 0,36 & 7,18 & 78,10 & 323,05 \\
\hline
\end{tabular}


Tabel 8. Kadar pati, gula total, dan serat kasar beras analog dengan penambahan kacang-kacangan

\begin{tabular}{lccc}
\hline \multicolumn{1}{c}{ Sampel } & Pati (\%bb) & $\begin{array}{c}\text { Gula total } \\
(\% \mathrm{bb})\end{array}$ & $\begin{array}{c}\text { Serat kasar } \\
(\% \mathrm{bb})\end{array}$ \\
\hline Beras analog + kacang kedelai & 61,56 & 1,94 & 13,25 \\
Beras analog + kacang hijau & 63,94 & 1,65 & 13,24 \\
Beras analog + kacang kara & 68,17 & 1,81 & 13,64 \\
Beras analog + kacang tunggak & 68,66 & 1,69 & 13,52 \\
\hline
\end{tabular}

Kanetro, 2015), sehingga ada peningkatan kadar serat dengan penambahan kacang-kacangan seperti ditunjukkan pada Tabel 8 yang bisa mendukung penurunan IG seperti diuraikan pada pembahasan selanjutnya.

\section{Indeks Glisemik (IG) Nasi Analog dengan Penambahan Kacang-Kacangan}

IG diamati melalui pengujian kadar glukosa sampel darah sukarelawan yang mengkonsumsi produk beras analog. Hasil pengujian ini diperhitungkan terhadap konsumsi glukosa sehingga mendapatkan nilai indeks glisemik (IG) seperti pada Tabel 9. Tabel ini menunjukkan bahwa nilai IG beras analog dengan penambahan kacang-kacangan digolongkan IG sedang (55-70) untuk kacang kara, IG tinggi (>70) untuk kacang tunggak, dan IG rendah $(<55)$ untuk kacang hijau dan kedelai, meskipun beberapa tidak berbeda nyata. Beras biasa (padi) dan singkong/ubi kayu digolongkan dalam bahan pangan ber-IG tinggi, karena nilai IG nasi dari beras putih $=$ 80 dan singkong $=73$. Hal ini merupakan permasalahan bagi penderita diabetes untuk mengkonsumsi nasi padi maupun singkong/ubi kayu. Sedangkan IG kacang-kacangan lebih rendah daripada beras padi dan ubi kayu, misalnya kedelai memiliki IG =31 (Marsono dkk., 2002).

Pada penelitian ini dibuktikan bahwa penambahan beberapa kacang-kacangan pada tepung growol atau oyek dapat menurunkan IG, sehingga produk beras analog yang dihasilkan bisa berfungsi sebagai makanan fungsional untuk mencegah peningkatan gula darah. Penurunan IG tersebut kemungkinan disebabkan peningkatan kadar serat seperti

Tabel 9. Indeks glisemik nasi analog dengan penambahan kacang-kacangan

\begin{tabular}{ll}
\hline Sampel & Nilai IG \\
\hline Nasi analog + kacang kedelai & $40,66^{\mathrm{a}}$ \\
Nasianalog + kacang hijau & $53,83^{\mathrm{ab}}$ \\
Nasianalog + kacang kara & $65,66^{\mathrm{bc}}$ \\
Nasi analog+ kacang tunggak & $76,66^{\mathrm{c}}$ \\
\hline
\end{tabular}

Keterangan: angka yang diikuti dengan notasi huruf yang sama pada kolom yang sama menunjukkan tidak ada beda nyata $(p<$ $0,05)$ ditunjukkan pada Tabel 8. Serat dalam diet dapat berberan sebagai penghalang absorbsi gula dan kolesterol dalam pencernaan (Muchtadi, 2012). Penurunan IG kemungkinan juga disebabkan oleh adanya protein kacang-kacangan pada produk beras analog. Protein kacang-kacangan mengandung asam amino arginin yang tinggi (Kanetro dan Dewi, 2013) yang telah diketahui mampu menstimulasi sekresi insulin sehingga bersifat hipoglisemik (Newsholme dkk., 2007; Kanetro dkk., 2008).

\section{KESIMPULAN}

Berdasarkan penelitian ini dapat disimpulkan bahwa jenis kacang-kacangan berpengaruh terhadap sifat fisik dan sensoris beras maupun nasi analog. Kadar protein beras analog dengan penambahan kacang kacangan dan nilai kalorinya hampir sama dengan beras padi yaitu berturut-turut antara 6,35-10,13\%bb dan 337,13-356,52 kal/100 g. Jenis kacangkacangan terbaik adalah kacang hijau yang memberikan nilai kesukaan keseluruhan tidak berbeda nyata dengan nasi padi. Indeks glisemik nasi analog dari oyek dan kacang-kacangan sebagian besar dikategorikan dalam bahan pangan berindeks glisemik rendah. Hal tersebut mengindikasikan beras analog hasil penelitian ini selain berpotensi sebagai pangan pokok pengganti beras padi juga sebagai pangan fungsional untuk mencegah diabetes.

\section{UCAPAN TERIMA KASIH}

Penulis mengucapkan terima kasih kepada Kementerian Ristek dan Dikti yang telah memberikan bantuan dana penelitiaan ini melalui Program MP3EI Tahun 2015.

\section{DAFTAR PUSTAKA}

Anonim (2010). Rencana Strategis Kementerian Pertanian Tahun 2010-2014. Kementerian Pertanian Republik Indonesia, Jakarta.

Anonim (2011). Metode Standar Penentuan Indeks Glisemik. Lampiran VI peraturan kepala badan pengawas obat dan makanan nomor hk.03.1.23.12.11.09909 tahun 2011. BPOM Republik Indoensia, Jakarta.

Anonim (1996). Daftar Komposisi Bahan Makanan. Direktorat Gizi Departemen Kesehatan Republik Indonesia. Bhatara Karya Aksara, Jakarta.

AOAC (1995). Official Standard of Analysis of OAC International, $16^{\text {th }}$ edition $\mathrm{AOAC}$ International, Arlington, Virginia. 
Eduardo, M., Svanberg, U., Oliveira, J. dan Ahrné, L. (2013). Effect of cassava flour characteristics on properties of cassava-wheat-maize composite bread types. International Journal of Food Science 4: 1-10.

Gomez, K.A. dan Gomez, A.A. (1995). Statistical Procedures for Agricultural Research, diterjemahkan oleh Endang, S. dan Justika, S.B. UI Press, Jakarta

Kanetro, K. dan Hastuti, S. (2006). Ragam Produk Olahan Kacang-Kacangan. Unwama Press, Yogyakarta.

Kanetro, B., Noor, Z., Sutardi dan Indrati, R. (2008). Potensi protein kecambah kedelai dalam menstimulasi sekresi insulin pada pancreas tikus normal dan diabetes. Agritech 28(2): 50-57.

Kanetro, B. dan Dewi, S.H.C. (2013). Pengaruh berbagai kecambah kacang-kacangan lokal sebagai bahan dasar meat analog terhadap sifat fisik (tekstur), kesukaan dan rasio arginin/lisin. Agritech 33(1): 1-7.

Kanetro, B. dan Luwihana, S. (2015). Komposisi proksimat dan kandungan bakteri asam laktat oyek terbaik dari perlakuan penambahan kacang tunggak (Vigna unguiculata) berdasarkan tingkat kesukaannya. Agritech 35(3): 261-265.

Kanetro, B., Luwihana, S. dan Setyowati, A. (2015a). Hypocholesterolemic and hypoglycemic of oyek with addition of cowpeas (Vigna unguiculata) sprout. Journal Food Process Technology 6(7): 65.

Kanetro, B., Luwihana, S., Sahrah, A, dan Pujimulyani, D. (2015b). Pengembangan Oyek Berprotein Tinggi Menjadi Beras Artificial dan Pembiasaan Konsumsinya di Dusun Sangon Kulon Progo DIY. Laporan Penelitian MP3EI Kemenristek Dikti. Universitas Mercu Buana, Yogyakarta.

Kartika, B., Hastuti, P. dan Supartono, W. (1992). Pedoman Uji Inderawi Bahan Pangan. PAU Pangan dan Gizi. Universitas Gadjah Mada, Yogyakarta.
Luwihana, S. (2011). Perubahan kimia dalam proses pembuatan beras oyek dari singkong, ubijalar dan kimpul. Seminar Nasional PATPI16-17 September 2011, Manado.

Luwihana, S. dan Kanetro, B.(2013). Pengembangan oyek berprotein sebagai pangan pokok dan pangan fungsional. Laporan Penelitian Hibah Bersaing Dikti, Universitas Mercu Buana Yogyakarta.

Marsono, Y., Wiyono, P. dan Noor, Z. (2002). Indeks glisemik kacang-kacangan. Jurnal Teknologi dan Industri Pangan 8(3): 11-16.

Muchtadi, D. (2012). Pangan Fungsional dan Senyawa Bioaktif. Penerbit ALFABETA, Bandung.

Newsholme, P., Brennan, L. dan Bender, K. (2006). Amino acid metabolism, $\beta$-cell function, and diabetes. Diabetes 55: S39-S47.

Stephenson, K., Amthor, R., Mallowa, S., Nungo, R., MaziyaDixon, B., Gichuki,S., Mbanaso, A. dan Manary, M. (2010). Consuming cassava as a staple food places children 2-5 years old at risk for inadequate protein intake, an observational study in Kenya and Nigeria. Nutrition Journal 9: 1475-2891.

Stupak, M., Vanderschuren H., Gruissem W. dan Zhang P. (2006). Biotechnological approaches to cassava protein improvement. Trends in Food Science and Technology 17: 634-641.

Sufa, T. (2012). Researchers produce 'artificial rice' from local plants. The Jakarta Post May 072012.

Saputro, K.E. dan Rahman, R.F. (2011). Pembuatan Beras Artficial dengan Bahan Dasar Ubi Kayu dan Tepung Porang. Laporan penelitian Jurusan Teknologi Industri Pertanian. Universitas Brawijaya, Malang. 